\title{
THE CASE AGAINST DIVINATION: AN EXAMINATION OF CICERO'S DE DIVINATIONE.
}

Ancient divination had something of the status of modern science. Diviners, like scientists, were expected to offer public comment on all manner of subjects, from strange meteorological phenomena to proposals for military campaigns, from shooting stars to Star Wars. In both cases this public responsibility is based upon a supposed expertise in prediction. And the arguments of those ancient philosophers who attempted to justify such a status for divination run in some ways remarkably parallel to those of modern philosophers who have attempted to justify such a status for science. Thus we are told both by Stoics and by modern Scientific Realists 1 that the world forms a single and unitary physical system, with nothing outside it to prevent the course of events from unfolding in accordance with the adamantine regularities which are the laws whereby nature operates. This determinism, and its consequence that the entire future of the world is already prefigured in the current state of things, makes it possible for us now to tell what will happen later. And that possibility is realised. Scientific predictions, we are told, may not be uniformly correct, but they are correct too often for that to be due to chance. The predictions of diviners, one must likewise concede, are not uniformly correct : nonnumquam ea quae praedicta sunt minus eueniunt (Cicero, De Divinatione, 1.24). Nevertheless, the Stoic argument against Sceptics would run, predictions were correct too often for their success to be a fluke. The point is illustrated by a forerunner of the ape who types out Hamlet: sus rostro si humi " $A$ " litteram impresserit, num propterea suspicari poteris Andromachen Ennii ab ea posse describi? (Div. 1.23). The predictive success of science therefore calls for an explanation; and this explanation, scientific realism declares, is to be found in the fact that the imperceptible objects spoken of in scientific theory - genes, viruses and electrons for example - really do exist more or less as described. Divinatory theory too speaks of imperceptible objects; and its predictive success was likewise alleged to need explaining by the existence of those imperceptible objects. But here comes a difference: the imperceptible objects posited by divination were not genes, viruses or electrons, but gods, and the Stoic argument for divinatory realism ran: si divinatio est, di sunt (Div. 1.10).

Hereafter, instead of concentrating on the parallels between science and divination, I will consider this difference and others consequent upon it. The Stoics, 
I will argue, were well aware of how divinatory prediction differs from its scientific counterpart; and for all the parallels between Stoicism and scientific realism, the Stoics consciously invoked these differences in their rationale for divination. Because of this, we will see that their rationale is remarkably successful. For since divination on the Stoic account does not even pretend to be scientific, it is altogether immune from the charge of being no more than pseudo-science. These points I will substantiate by setting out the Stoic case for divination, and by showing how ineffective against it are the arguments of Cicero's De Divinatione.

To begin. Consider a, or the, Stoic divinity. He organises and animates a marvellously structured deterministic world. One of his names is Heimarmene, or Fate. Just as human beings know of their intentional actions, so too he knows of exactly what will happen; for whatever happens, he has designed and decided upon. As Div. 2.102 puts it: neque [di] ignorant ea quae ab ipsis constituta et designata sunt. Now among those subject to his benevolent care and control are human beings; and those human beings would clearly be helped if they come to share in his knowledge of the future that he has mapped out. Of course, this does not make it desirable for human beings to know every detail of the future. No doubt there are, as Div. 2.22 points out, certain subjects ignorance of which is bliss: quae enim uita fuisset Priamo, si ab adulescentia scisset quos euentus senectutis esset habiturus? (cf. N.D. 3.14). But it would be illicit to infer from the fact that ignorance is sometimes bliss the conclusion that it is always so. For sometimes knowledge can help. This is not because when human beings know that something will happen they are thereby enabled to prevent it happening. That of course is absurd, for one cannot make false what one knows to be true. Cicero asks a few rhetorical questions, insinuating that some such absurdity is needed if humans are to be helped by knowledge of their future. Thus N.D. 3.14: quid igitur iunat aut quid adfert ad cauendum scire aliquid futurum, cum id certe futurum sit? (cf. Div. 2.20). In fact however no such absurdity is needed. If people know what is in store they can use that knowledge to plan their actions accordingly, to take advantage of good fortune or to mitigate the effects of bad. The point of knowing that the train will leave at eight is not to stop it leaving then, but to be at the station on time. And above all of course, it will help human beings if God can impart to them conditional information, for instance that God will favour them if they proceed with some projected battle or assembly. Here again this knowledge is not rendered pointless by the fact that they can do nothing to make it untrue that God will favour them should they proceed. On the contrary, the very unalterability of this conditional fact is what makes it so reliable a guide to action.

Here I will mention, only to sidestep, a much deeper difficulty for the Stoic God in imparting useful knowledge to human beings. It is this: in a world where all is subject to the control of fate what scope can there be for human beings to plan their lives? The Stoics were asked this question. In particular they were asked it in discussion about divination (cf. Stoicorum Veterum Fragmenta 2.939). And they 
had lots of answers to it. Nevertheless, this question, and the Stoic answers to it, have no special connexion with divination. Free will in a fated universe is no harder to explain - nor for that matter any easier - if that universe contains divinatory predictions than it if does not. In any case, Cicero does not press this difficulty. Nor shall I. I shall simply assume (what is not in fact the case) that the Stoics have an adequate answer to the question, and press on.

To recapitulate. The Stoic divinity wants human beings to share some of his knowledge about the future. How then can they do this? In a deterministic universe one way at least is obvious. Human beings can know something of the future by knowing the laws whereby things operate and by using these to infer future effects from present causes, or, more generally, to infer the unobserved parts of a causal process from those that have been observed. Human beings can in short make scientific predictions. A paradigm, instanced in Div. 2.17, is the astronomical prediction of lunar eclipses that one can derive from an understanding of how and why such events occur.

The Stoics, we should note, allow rather more predictive practices to count as scientific prediction, dependent on causal knowledge, than we perhaps would. Thus they allow that we can predict, with some reliability, a man's intellectual attainments from his place of origin. Thebans, for instance, are strong and stupid (Fat. 7). But the significant thing is that these predictions too are based on some putative scientific knowledge of natural laws connecting cause with effect. One predicts the stupidity of a Theban because of some supposed causal connexion between climate and character. Nevertheless, although Stoics would put more in their category of scientific prediction than we would, they clearly do have such a category. And by and large they are insistent that divination does not belong in it. ${ }^{2}$

For the fact is that scientific prediction cannot get us far enough. Lots of things aren't covered by any causal laws that we know of. These are the things that are thought to be fortuitous, the res quae fortuitae putantur of Div. 1.9. Knowledge of them too would be no less useful than knowledge of what is scientifically predictable, yet here scientific prediction is impossible. Because of this, what we might call Cicero's Other Sciences Argument goes wide of the mark. He asks (Div. 2.9-12; cf. 2.121-3) what scope can divination have. Do not the senses, medicine, musicology, astronomy, geometry, philosophy, statescraft and the like between them cover everything? And who would seek a diviner's advice on any subject of that sort? True enough, medicine and its kin cover all that scientific means can predict. And in these areas there is little role for a diviner to play. But the fact is that there are many other areas in which foreknowledge would be desirable but in which scientific foreknowledge of effects from causes is simply unavailable. It is here that divination has its place: for divination est earum rerum quae fortuitae putantur praedictio atque praesensio (Div. 1.9). Note that because of this there is no need for rivalry between science and divination: the very fields in which divination is to operate are defined as those for which we have no science. 
But is not the scientifically unpredictable wholly unpredictable? Cicero makes much of the fact that what is fortuitous is wholly unpredictable, whether by scientific means or by any other. Thus Div. 2.15:

potestne igitur earum rerum, quae nihil habent rationis quare futura sint, esse ulla praesensio? quid est enim aliud fors, quid fortuna, quid casus, quid euentus, nisi cum sic aliquid cecidit, sic euenit, ut uel non cadere atque euenire uel aliter cadere atque euenire potuerit? quo modo ergo id, quod temere fit caeco casu et uolubilitate fortunae, praesentiri et praedici potest?

The Stoics can and would concede this point. And Chrysippus at least would go further. He would insist that if something is genuinely random, if, that is, there is now no sufficient cause for its happening, nor any for its not happening, then the Law of the Excluded Middle fails and it is not even true that the thing will happen, nor yet that it will not; in which case a fortiori neither of these things is knowable (Fat. 20; cf. 32-3). ${ }^{3}$ But this concession does no damage. For the Stoic position is not that things scientifically unpredictable are in fact fortuitous, and thus wholly unpredictable. It is rather, as Cicero himself has reported earlier, that such things are thought fortuitous; though of course, being under the control of an all-powerful fate, they are not actually any more fortuitous than those things that we can predict from knowledge of their cause. The apparently fortuitous may well then be predictable by other means.

We noted earier that science and divination are saved from rivalry by finding for each a separate domain. We should note now that the Stoic technique for preventing rivalry differs from some of its modern counterparts for preventing rivalry between science and religion by giving them separate spheres. The Stoic separation does not find for divination a sphere that is, as the phrase goes, "in principle' inaccessible by scientific means, a sphere of the supernatural, or the spiritual, where laws of the sort discerned by science hold no sway. The Stoic sphere for divination is as much a part of the single corporeal and deterministic universe as is the Stoic sphere for science.

But by what means other than science will we be able to share in the divine knowledge of the future? Some of that knowledge, it is suggested, human beings can have in just the same non-inferential fashion that gods do. Thus (Div. $1.70 ; 1.66$ etc.) when we are dreaming or frenzied, our little share in divinity, the human soul, may be to some extent liberated from bodily restraints, and in the thoughts that then come to it our soul will share something of the foreknowledge of that divinity which is its source. Maybe so; but even when this so called 'natural' or 'artless' divination is added to scientific prediction human beings will still not know all that they need to know.

How then can the benevolent god of Stoicism impart to human beings the full knowledge that they need? Quite simple. He tells them. He engineers events which are meant as statements about what he has in mind for the future. If human beings 
have any sense they will notice these events, recognise that they have been engineered to express to them God's plans for the future, believe the statement that God thereby makes about how things will go on, and thus will themselves come to share in God's foreknowledge. The events from which diviners predict things thus have what Paul Grice has dubbed and analysed as 'non-natural meaning': they mean the facts they signify, not in the way that clouds mean rain, but in the way that a road sign means a bridge ahead. ${ }^{4}$ Understanding these events is a matter of understanding a message, a communication. And to understand and believe messages about the future is altogether different from coming to know of the future by reasoning from present causes to future effects. The little marks that I read in my time table don't cause the departure of the train; nor in using them to learn when the train will leave do I apply any scientific knowledge of what makes trains move. I simply recognise these marks as stating the time at which the train will leave, and as having been put there so that by recognising the purpose with which they were put there I can come to share in the knowledge of train departures possessed by those who plan such things. According to the Stoics, divination is like reading a timetable: it is the interpretation of messages from the gods.

I have called the meaning of an omen a 'non-natural' meaning. I should here attempt to say a little more exactly what that comes to. The point is not that omens form no part of the natural causal order. To be sure, they are engineered, planned and intended by the gods. But so, on the Stoic account, is everything: there is nothing that happens without its being planned by the gods to happen just as it did. Nor is the point that omens get their meaning by a convention. To be sure, diuturna obseruatio (Div. 2.124) may enable us to tell that gods regularly employ certain signs to express certain messages, just as when travelling abroad frequent observation may enable one to tell the meaning with which a road sign is conventionally endowed. But not all omens are like this. There is the possibility of a one-off communication, not invoking any regular conventions; and likewise there is the possibility of a one-off omen. The 'non-natural' meaning of an omen consists rather in this: it is produced with the twofold intention that first, its auditor form a certain belief, and that second, he do so because he recognises that the omen was produced with the first intention.

The idea of omens as communicative may be illustrated by several things. First, there is the vocabulary used by Stoics to describe what is predicted through omens. These things are a dis significata (Div. 1.101); or quae ab eis [sc. dis] significantur (Div. 1.104); or as N.D. 2.12 puts it: signa ostenduntur a dis rerum futurarum. In particular, the omens themselves are said to make statements about the future: it is not merely that we use them as evidence for making such statements ourselves. Thus Div. 1.35 says that omens predict, praedixerint; Div. 1.127 speaks of signs that declare what is to follow, consequentia declarantibus; and according to Div. 1.29 all manner of divinatory signs announce the future, nuntiant euentura. Above all, it is striking how, whether rightly or wrongly, the vocabulary of ostenta, portenta, 
monstra, and prodigia is given etymologies from verbs of communication. Prodigia for instance is derived from praedicere (N.D. 2.7)

Second, there is the analogy between divination and philology. Diviners are interpretes of signs, ut grammatici poetarum (Div. 1.34; cf. 1. 116 and N.D. 2.12). And the job of the grammarian is to understand words not by reasoning from them as causes to their future effects, but by working out what they say.

Third, there are explicit and frequent denials that in understanding signs one either uses or is given any scientific knowledge of cause and effect. Omens of all sorts non causas afferunt cur quid eueniat, sed nuntiant euentura nisi prouideris (Div. 1.29; cf. 1.23, 1. 127).

Once omens are taken as messages divination becomes quite a comprehensible practice. All the features of divination that would make it quite grotesquely dotty if it were an attempt at scientific prediction of effects from causes fall into place as just what is to be expected from interpreting divine communication. Let me demonstrate this by running through the remainder of Cicero's arguments against divination. Each would be damaging, and collectively they would be devastating, if divination were claimed to be a sort of science. But the whole point of the Stoic theory is that science is one thing, and divination another. Cicero simply misses this point. His arguments are no more than variants on the rhetorical question of Div. 2.29: quid habet naturale quod declarare possit quid futurum sit?; a rhetorical question to which Stoics have the quick reply that an omen's meaning is not natural, but instead the sort of meaning that belongs to a significant utterance. In missing this point Cicero makes on the large scale the same sort of error that we have already seen him making on the small in his complaint that the Stoics take divination to deal with the actually fortuitous, rather than just with the apparently so.

I will divide my material, somewhat arbitrarily, into seven heads.

First, Cicero argues from the triviality of certain signs. How, he asks in Div. 2.56, could a silly little thing like the crowing of a cock presage the victory of a great city in battle? Now it may be true that a grand event needs a cause of equal grandeur. But however grand the event, something quite trivial can be used to announce it in advance. You can be told the time of an eclipse by what in themselves are the trivial little marks in an almanac, though no doubt so grand an event as an eclipse has a correspondingly grand cause in the motions of sun, moon, and earth.

Second, Cicero argues from the sheer arbitrariness of the connexion between portents and what they portend. Thus at Div. 2.34 he demands: what possible connexion could there be between financial gain and a certain sort of fissure in a liver? Likewise Div. 2.65 demands: why on earth should the number of sparrows in an omen indicate a number of years rather than a number of months, or of days? These connexions remain quite arbitrary, he insists, even when full account is given to the Stoic notion of sumpatheia, the harmony that binds the cosmos together. Again, Cicero's argument misses the point. Pace perhaps David Hume, causes are 
no doubt not arbitrarily annexed to their effects. There must be some traceable and comprehensible connexion between the two. But there need be no such connexion between future events and the statements which foretell them.

Third, Cicero argues from the unsystematic character of divination. A thunderbolt on the left, he reminds us twice (Div. 2.43, 2.74), is a favourable omen in all circumstances save when it is proposed to hold an election. Now a cause no doubt will not be responsible for two different effects. The Stoics would agree with this point. Indeed, they would insist on it, as a corollary of their belief in the lawfulness of causation. ${ }^{5}$ The thunderbolt therefore is not cause of the good or ill fortune that it presages. But so what? It need not cause these things to communicate information about them. And what is communicated by human words is often unsystematic. Think of how many meanings, in different contexts, the sound 'rose' can bear. Why should divine utterances be any more systematic?

Fourth, Cicero appeals to national differences in the interpretation of omens. Div. 2.28 points out how differently chicken entrails are interpreted by the soothsayers of Etruria, Elis, Egypt and Carthage. In Div. 2.76 Cicero exclaims on the differences over interpreting the flight of birds that he as a Roman learnt of when talking with the Asiatic Deiotarus (cf. 2.80). In like vein Div. 2.82 contrasts the Roman practice of interpreting thunder on the left hand as favourable with the Greek and barbarian practice of giving such an interpretation to thunder on the right. But these national differences are no embarrassment to the Stoic. Of course, the causal powers of entrails, bird flight, and thunder are exactly the same regardless of cultural boundaries. But language can and does differ. Thus Americans interpret the words 'second floor' to mean one part of a building, the English to mean another, and both are quite justified. Moreover, if you want to communicate something to English or to American people you take their different interpretative practices into account and adjust your wording accordingly. In America you'd say 'second floor', whereas in England you'd say 'first'. Why should the divine utterances in which the gods communicate to us their plans for the future be exempt from this general principle that one chooses the wording of one's messages to different audiences with one eye to how those different wordings will be interpreted?

There is one important consequence of this. We have special grounds for complacency about the reliability of our procedures for interpreting omens that we lack for complacency about our natural science. There is every reason to doubt that the order of cause and effect will adjust itself in different cultures to accord with the different expectations of those cultures. But such an adjustment is exactly what we should expect from divine utterances addressed to different cultures with different ways of understanding them. ${ }^{6}$

Myles Burnyeat has pointed out a particularly striking corollary: Stoicism justifies so great a complacency about our habitual interpretation of omens that in an important sense Stoicism leaves no room for misinterpretation. Suppose I take 
something to be an omen telling me of good fortune to come, and believe it. Now in the Stoic universe nothing is accidental: all that happens happens just as the gods have planned. In particular therefore they produced the event which I take to be a good omen with the very intention that on seeing it I acquire a belief in good fortune to come. What is more, I acquire this belief through recognition of this intention of theirs; and that too they intended. I am therefore bound to be right. The conditions for "non-natural" meaning have been met, and the event genuinely is an omen telling me of future good fortune. How then, unless the gods lie, can someone be led by omens into false beliefs? What scope is there for expertise in divination? What can remain of the Stoic contention that only the sage is a true diviner $(S V F 3.605$, 607)?

On one point the Stoics are clear: it is one thing to say something false, and another to tell a lie. The falsehoods that even the sage will tell to deceive an enemy, or to entice sick children to take their medicine, are not in any strict sense lies ( $S V F$ $3.554,555)$. Apply this idea to the gods and they can be acquitted of lying even though what I rightly interpret them as telling me is in fact false. Different levels of divinatory expertise would therefore amount to this: all are equally adept in understanding what the gods say, but it is only to the wise that the gods will uniformly tell the truth. The rest of us are like children who may need to be deceived for their own good, or like malefactors who need to be deceived for the good of others; and it is because we are foolish in these respects, rather than because we misunderstand the gods, that our divinatory predictions will sometimes be false. This raises the further question: how in a world controlled by the Stoic providence can there be any need for deception? How indeed is deception even possible? This question however is one that the Stoics face anyway, quite apart from considerations of divination. It is nothing other than an aspect of the much discussed ( $S V F 2.1168-1186$ ) problem of evil. I will therefore consider it no further here.

A fifth point of Cicero's is this. Where there is some non-arbitrary discernible connexion of portent with portended, that connexion is too often punlike, or symbolic. Consider these cases:

Div. 1.74 a cock crows, which portends victory;

1.78 there are bees on Plato's lips, which portends a suauitas orationis;

1.104 Caecilia offers her niece a chair with the words 'I give you my seat', which portends the marriage of her niece to Caecilia's husband after she is dead;

2.47: A statue of Romulus is struck by lightening, which portends danger for the city of Rome;

2.134: Someone dreams of an egg beneath his bed, which portends that he can find there some treasure consisting of gold surrounded by silver as the yolk is surrounded by the white.

Now of course it would be a silly superstition to imagine that there is any causal connexion in these resemblances and affinities between portent and portended that 
make the one so apt a symbol of the other. The world, we know, does not work like that: what is salient for us need have no causal significance. But the world need not be supposed to work like that for such things to be used in prediction. The very feature of these portents which makes them so unlikely to be causes of what they portend - their superficial and punlike connexions with it - makes them an eminently suitable sign for gods to use in communication. Borges' story "The Garden of Forking Paths" affords a delicious illustration. A spy wants to communicate to his German masters the information that the British have sited their artillery near the town of Albert. He gets himself arrested by murdering a man called Albert. The idea is that his controllers in Germany will read the papers and make the connexion between Albert the man and Albert the town. Which they do. But of course, in doing so they need not in the least suppose that an attack on Albert the town is caused by an attack on Albert the man.

Cicero's sixth point is to make much of the ambiguity of omens. Div. 2.144-5 lists examples where two conflicting interpretations are offered of the self-same portent; and contrasts this unfavourably with the straightforwardness of the signs which physicians and pilots go by. Such an ambiguity means of course that divinatory signs are not causal. But it is alas exactly what we must expect from signs used as means of communication. For, as Chrysippus pointed out, no communicative sign has any one meaning intrinsic to it. In the words of $S V F 2.152$ 'every word is ambiguous by nature, since from the self-same word two or more things may be gathered'.

The seventh complaint is this. Diviners make much of marvellous portents, yet their marvellous character is entirely subjective. In the words of Div. 2.49, causarum ignoratio in re noua mirationem facit. We marvel at some event only when it's something we've not seen before and we don't understand its cause. Take away either the novelty or the ignorance and the event will no longer be marvellous. Now Cicero's definition of what makes something marvellous is no doubt quite correct to make marvellousness subjective. And it is no doubt correct also to infer from this that the marvellousness of an event can therefore give it no power to produce the forthcoming events that it portends. But so what? The marvellousness of an event, however much it exists only in the eye of the beholder, does not unfit it for use in communication. If you want to send a message, you must ensure that its recipient realises a message is being sent. Often enough you and the recipient will have some established convention so that he will know in advance where to be looking. But if not, you will have to make your message eye-catching and spectacular for it to catch his attention. You must, in short, aim to produce miratio.

Stoic divination therefore emerges unscathed from Cicero's criticisms. It does so because the criticisms judge it by the standards of natural science, whereas in fact it is put forward to go alongside lexicography and literary criticism as a branch of applied semiotics, concerned with understanding the utterances of the gods. If it is to be attacked successfully it must therefore be attacked on theological grounds. 
And it was on theological grounds, more specifically Christian ones, that the successful attack was made. This attack accepted the Stoic claim that in practising divination one acknowledges the existence of the pagan gods. Yet interestingly enough it did not proceed to argue against the practice of divination on the grounds that there existed no such beings. Tertullian (Apology 22) is a case in point. He is too impressed by the divinatory realist argument to argue in such a way. Pagan oracles do work often enough for their success to need explanation, and the explanation is indeed that in oracles one receives messages from supernatural beings. But those supernatural beings can only be fallen angels. To practice divination is therefore to be in communication with the enemy. And this was why Christians, while they were happy to accept all the pagans' other means of prediction, all the pagan sciences, nevertheless could not accept pagan divination.?

\section{NOTES}

1. See e.g. J. J. C. Smart, Philosophy and scientific realism (1963).

2. Boethus and Posidonius (Div. 1.13, 2.47) may be partial exceptions to this, if they did indeed attempt to offer meteorological explanations for the predictive reliability of certain omens. Nevertheless, we have no reason to believe that they would have thought scientific explanations available for every apparent omen, nor any reason to doubt that they would have thought such explanations for every apparent omen tantamount to explaining divination away.

3. There is a similar belief among some modern scientific realists that the failure of determinism in quantum mechanics requires a modification of our customary logic. See e.g. Hilary Putnam, Philosophical Papers I (1979) 174-197.

4. H. P. Grice, 'Meaning', Philosophical Review 66 (1957) 377-88. Grice's ideas have been much elaborated in Stephen R. Schiffer, Meaning (1972). Simon Blackburn, Spreading the Word (1984) 11018 has shown how to cut through many of the complexities found in other developments of Grice's ideas. In this paper I intentionally avoid all such complications, since what I have to say can stand with appropriate modifications however Grice's insight may eventually be spelled out.

5. See Richard Sorabji, 'Causation, laws and necessity', in Malcolm Schofield and others (eds.), Doubt and Dogmatism (1980) 250-282.

6. On the adjustment, typically mutual, of the expectations of speakers and their audiences, see Jonathan Bennett, Linguistic Behaviour (1976) 176-202.

7. This paper derives from talks I have given at the Institute of Classical Studies, London, the University of Western Australia, Perth, and the Philological Society, Cambridge. Kind audiences on each of the three occasions have been responsible for many improvements. 